\title{
WIKILEAKS UNDER FIRE: IS IT ELECTRONIC CIVIL DISOBEDIENCE?*
}

\author{
Miquel Comas Oliver
}

\author{
Universitat de les Illes Balears \\ miquelcomasoliver@gmail.com
}

\begin{abstract}
:
This paper evaluates the usefulness of the civil disobedience theory to legitimate the e-leaking of secrets, i.e. ethical and electronic disclosure of confidential information. First, the main definitions of offline civil disobedience are reviewed. Liberalism established the dominant set of validity conditions: symbolic, peaceful, responsible, public, constitutionally loyal, etc. I criticize this standpoint thanks to the discursive approach, but also highlighting its prejudices. Second, I analyse whether WikiLeaks meets those classical requirements. Encrypted anonymity, partial decriminalization and limited irresponsibility become acceptable. Regarding publicity, the disobedient visualization of a political conflict can be satisfied without revealing the identity of its participants.
\end{abstract}

\section{Keywords:}

WikiLeaks, Electronic Civil Disobedience, Deliberative Democracy, Whistleblowing, Anonymity.

\section{Resum:}

Aquest article avalua la utilitat de la teoria de la desobediència civil per a legitimar l'efiltració de secrets, això és, la revelació ètica i electrònica d'informació confidencial. En primer Iloc, es revisen les principals definicions de desobediència civil offline. El liberalisme va establir el conjunt dominant de condicions de validesa: simbòlica, pacífica, responsable, pública, Ileial constitucionalment, etc. Critico aquesta posició gràcies a la perspectiva discursiva, però també destacant els prejudicis d'aquesta última. En segon Iloc, analitzo si WikiLeaks satisfà aquells requisits clàssics. Anonimat encriptat, descriminalització parcial i irresponsabilitat limitada esdevenen acceptables. Pel que a la publicitat, es pot assolir la visualització desobedient d'un conflicte polític sense revelar la identitat dels seus participants.

\footnotetext{
* This paper is an abridged, updated version of a presentation held in the 13th Political Philosophy Conference Displacements of Power and Criticism (University of Barcelona, 2016). I am very grateful to Justo Serrano for his contributions to its revision.
} 


\section{Paraules clau:}

WikiLeaks, desobediència civil electrònica, democràcia deliberativa, Whistleblowing, anonimat.

Recibido: 10/02/2017

Aceptado: 17/03/2017

\section{INTRODUCTION}

This article's main objective is to answer the following question: Is it appropriate to use the concept of civil disobedience to analyse the ethical leak of secrets, primarily starring by WikiLeaks, the portal founded by Julian Assange?

To start with, I propose the neologism e-leaking to describe any act of classified data leaking to occur today, ${ }^{1}$ whether it is done by anonymous actors on the network as traditional mass media or investigative journalists, regardless of the use of cryptography and anonymity. ${ }^{2}$

This very condition of anonymity is one of the most crucial issues to take into account, since most of the research on civil disobedience on the Internet has not paid attention enough to it. ${ }^{3}$ In fact, it is taken for granted that the anonymity could not be

${ }^{1}$ Obviously, the adequacy of e-leaking to the discourse of civil disobedience could be used to justify (or condemn) many more actors and social digital movements than WikiLeaks. Moreover, the adaptation of civil disobedience to the Internet would allow analysing actions other than revealing secrets, which thus appears just as one possible subtype of e-disobedience or electronic civil disobedience. For example, the DDoS attacks - distributed denial-of-service attacks - practiced, among many others, by Anonymous (cf. Padilla, 2012: 47-81). Or the free distribution of software or copyrighted content through file sharing tools peer-to-peer (P2P).

${ }^{2}$ The reason for this all-encompassing scope, including any form of whistleblowing, lies in the fact that it is inevitable the use of Information and Communication Technologies in that practice. Nowadays, any theft or disclosure of data must be electronical, and not by materially carrying what in the physical world would amount to several tons of paper documents - which is how the disclosure of The Pentagon Papers was accomplished, just to mention one of the most famous episodes. Hence one of the two possible meanings of the letter " $\mathrm{e}^{\text {", }}$, in addition to "ethical", in the prefix of the term e-leaking.

${ }^{3}$ For instance, Wray (1998) claims that while political hacktivism is allegedly practised in secret and anonymously, principally because of its illegal nature and the consequent risks involved, electronic civil disobedience should be performed openly and its agents should not hide their names or identities. Scheuerman (2014) does dare to question the condition of responsibility but not anonymity. In fact, he seems to intensify the requirement of publicity in order to accept Snowden's acts as fair, in contrast with NSA secrecy. 
at all a feature of the incipient electronic civil disobedience. The reason is crystal clear: political traditions do require the condition of publicity to disobeyers. ${ }^{4}$ And this assumption makes it very difficult to include whistleblowing as civil disobedience, as far as the informants are normally unknown. Consequently, first the classical definitions of civil disobedience must be reviewed to explore if it is possible and consistent to accept the anonymity, among other items, in its extrapolation to cyberspace.

The normative background of this paper is the philosophical tradition of Critical Theory, undertaken by the famous Frankfurt School and most prominently by J. Habermas. ${ }^{5}$ The main reason to refer to the deliberative approach is that it allows justifying ethical leaking more acceptably, something that WikiLeaks and Julian Assange have not done enough. The latter's arguments are based in an unspoken "fundamental norm" - it is legitimate to violate the applicable secret law if you reveal a crime or an immoral act-, appealing to many different reasons and theories, not necessarily consistent. For example: liberalism, human rights, ${ }^{6}$ sui generis constitutionalism, utilitarianism, and even anarcho-capitalism. ${ }^{7}$ Therefore, I find it crucial to validate the e-leaking based on a just and participatory conception of democracy, which is achieved by connecting such an action with the discourse of civil disobedience and Critical Theory.

\section{OfFLINe CiVIL DisObedienCE}

In truth, the most interesting perspective to address the problem is the following: it is obedience which must be theoretically and politically justified, not disobedience. As well presupposed Hobbes (2012), the obedience of the people to law is not a natural or valuable phenomenon per se, and therefore it should be normatively justified.

This incipient contractualism in Hobbes radicalized an inalienable freedom of the individual that, afterwards, approached political liberalism to the understanding and even the defense of civil disobedience. In fact, the definition of civil disobedience that

${ }^{4}$ It is generally understood that the disobedient subject informs of his intentions well in advance, warning the whole society - police included- of space and time in which he would hold its symbolic and illegal act. The public nature of the action gives greater credibility, value and justice to disobedience. And tacitly, the identity of the authors is included in that publicity.

5 Habermas (1988) defines Critical Theory as an overcoming of the monological and subjectivist modernity. Cf. Fraser \& Honneth (2003) to understand the key normative concept of "surplus validity", which explains the dialectic between the given and the desired. This dialectic is immanent because it is developed within the social relationships.

6 "We derive [our] principles from the Universal Declaration of Human Rights. In particular, Article 19 inspires the work of our journalists and other volunteers. It states that everyone has the right to freedom of opinion and expression; this right includes freedom to hold opinions without interference and to seek, receive and impart information and ideas through any media and regardless of frontiers. We agree, and we seek to uphold this and the other Articles of the Declaration" (WikiLeaks, 1.1).

${ }^{7}$ Cf. Comas (2011a; 2011b; 2012a \& 2012b) for my analysis on these various bases of eleaking, not always harmonious. 
both academically and socially prevails today is defined by liberalism: a public, responsible, peaceful, conscious and highly political act - because the reason for its illegality is to promote the modification of the violated law. ${ }^{8}$ Liberal scholars understand and support the decision to flout a standard that can violate their personal convictions or their most private sphere of autonomy. Moreover, they even consider the tolerance of disobedience as an indicator of the democratic quality of a genuine liberal society. Of course, they do not advocate its legalization or decriminalization. In addition, they severely restrict its practice, by imposing specific requirements, such as having previously exhausted all legal avenues, or the prior and general loyalty to the constitutional order.

For his part, Jürgen Habermas (1985a: 99) understands disobedience as "acts of protest [that] - even if they represent calculated infringements of rules- can have only a symbolic character and may be executed solely with the intention of appealing to the capacity for reason and sense of justice of the majority". Although it is possible to be performed through physically blunt actions, Habermas points out that its role and objective is to appeal to the sense of Right, Law and Justice that the citizenship majority has. That is, it is a "call to an examination of conscience" or an action that interpellates the public opinion, a key concept in the Habermasian democratic theory, deliberationism. Hence he affirms: "Only the threat of forfeiture of its legitimacy can bring the government around". ${ }^{9}$

In short, Habermas holds that current laws can only be presumed fair if, in their promulgation by majoritarian elections, this majority respected pre-legislative normative standards of legitimacy. And these criteria are only obtained by judicious, voluntary and intersubjective recognition of citizenship. ${ }^{10}$ If the State is only based on the current law, there is not absolutely any requirable obedience. Only if justice and democracy exist, compliance with the laws can be expected; but conditional, never absolute, since compliance is subject to a moral justice greater than law. Thus, the validity of the very fundamental norm and the due obedience are based on pre-legal

\footnotetext{
${ }^{8}$ Rawls (1999). Dworkin (1978) conceives civil disobedience as the self-correcting mechanism that democracy offers to its citizenship to convince and motivate, as long as civil disobeyers act in favour of the public interest.

${ }^{9}$ Thus, civil disobedience would include "acts that, although the form of which is illegal, they are carried out with appeal to the legitimating foundations of our democratic constitutional order [...] to awaken the willingness for renewed consultation and decision on laws or policies, and to give impetus to a revision of a majority opinion" (Habermas, 1985a: 99-100, italics mine).

10 "The constitution must be capable of justification on the basis of principles the validity of which may not be dependent upon whether or not the positive law conforms with them. The modern constitutional state can therefore only expect of its citizens obedience to the laws if and in so far as it rests on principles worthy of recognition, in light of which that which is legal can be justified as legitimate - and, if necessary, can be rejected as illegitimate. [...] A democratic constitutional state can demand of its citizens not an unconditional, but rather only a qualified obedience to the law, because it does not ground its legitimacy in sheer legality" (Habermas, 1985a: 102, italics mine).
} 
social relations of recognition, which are the nuclear field of the sovereign subject or the constituent power of the constitution. ${ }^{11}$

So, Habermas proposes the institutionalization of some suspicion and surveillance for the law, just in case it conceals injustice, in order to "recognize the legal offenses against legitimacy and, if need be, to act illegally out of moral insight" (Habermas, 1985a: 103). Thus, civil disobedience is the only instrument available against "institutionalized crime".

Despite the above, at least two interconnected problems are observed both in Habermas' conception of civil disobedience as in the liberal one. First, it tacitly involves only two actors: the disobedient and the national State. This Westphalian myopia or methodological nationalism incapacitates to properly understand the actions of NGOs or cyberactivists in the transnational level. ${ }^{12}$ Second, it connects civil disobedience with the necessary existence of a solid and mature democratic structure. I agree with various authors (Iglesias, 2002, etc.) on the criticism to these two assumptions. ${ }^{13}$ The previous acceptance of the general validity of the rest of the national legislation is an excessive and outdated request. The current international framework -defined by, inter alia, the prevailing neoliberal globalization,

${ }^{11}$ Habermas (1985a: 102) refers to the Kantian tradition of rational law and "the insight that only those norms are justified which give expression to a generalizable interest and thus could count on the considered agreement of all concerned. This agreement is linked to a procedure of reasoned will formation". The difference with liberalism lies in the fact that the discrepancy between law and legitimacy does not reproduce a conflict between a public morality and a private morality "of privileged access", but between a public positive legislation and a normative principles also public. Habermas is totally aware of the problem of the justification of the alleged legitimacy that must assess the law; therefore he avoids any definition based on an inherited or objectivist conception of truth; he always refers to a critical and discursive methodology.

${ }^{12}$ WikiLeaks $(1.3 \& 3.2)$ : "We believe that it is not only the people of one country that keep their own government honest, but also the people of other countries who are watching that government through the media. [...] Which official will chance a secret, corrupt transaction when the public is likely to find out? What repressive plan will be carried out when it is revealed to the citizenry, not just of its own country, but the world?".

${ }^{13}$ A third problem could be Habermas' refusal to the legalization of civil disobedience. He merely defends its prosecution as "unusual" or "uncommon" crime, and the eventual absence of penalty in specific cases, to overcome the "authoritarian legalism", but not its total decriminalization. Habermas (1985a: 106) believes that if civil disobedience is legalized, it would lose its character of personal action with "intrinsically" associated risks, something that would question its moral base and even undervalue its convening power. In my view, his argument is invalid, contingent and inconsistent with his very deliberationism. Legalization - which should be extremely rigorous in any legal casuistry, of course- would be useful to give much more legal certainty to both citizens and democratic institutions, by distinguishing more clearly between crimes made up with rhetoric, by a side, from true civil disobedience, on the other. In that sense, we could propose a new indicator of democratic quality of a political community, state or not: the positive legal recognition of the right to civil disobedience. I insist: with its indispensable scrupulous legal formulation, that would not exempt from an exemplary sanction for the abuse of that right or its fraudulent use. 
informational capitalism, etc.- could not be deemed as a global rule of law. Therefore, if we are to understand the current great diversity of actors as examples of civil disobedience, we should change its definition. Otherwise we can only describe them as resistance or self-defense. In this case, social movements will face much bigger risks of delegitimization, criminalization and effective destruction.

\section{Online Civil Disobedience: The CASe Of WikileAKS}

At this stage of my argument, I should analyse the general circumstances that predetermine any kind of social action in Cyberspace, because our assessment on the possibility and adequacy of electronic civil disobedience depends on them. For reasons of space, however but I am only in a position to merely outline the following two hypotheses, based upon different authors: ${ }^{14}$

a) There are no guarantees or democratic rights recognized in cyberspace yet.

b) Nevertheless or precisely because of this, the Internet is a new effective and legitimate political scope for social or citizen actions and movements, as "a new public-private sphere" that connects the denunciation of the digital precariousness with the claim on cyber rights and the Net Neutrality. ${ }^{15}$

Because of this absence of an adequate legislation, Internet battles have extremely high costs and risks, both economically and judicial. Even biological, because sometimes they endanger life itself. ${ }^{16}$ As an inevitable conclusion of the above, I will

${ }^{14}$ See Padilla (2012); Stallman (2010); Zafra (2010); de Ugarte (2004 \& 2011); Castells (20002001); etc.

${ }^{15}$ In addition, there is an obvious economic dimension in this struggle: "Because copyright is partly an economic right, the struggle for freedom of access to the new wealth is both an economic struggle - against the artificial scarcity - and political - for the recognition of freedoms in the Cyberspace. Since in cyberspace there is still no recognized right, the fight against censorship is protected in the old protectionism and shelters itself in the right to freedom of information and press" (Padilla, 2012: 61-62, my italics). "The digital revolution, this new cultural event arising from the technological convergence of electronics, software and telecommunications infrastructures, all of it infiltrated by the hacker counterculture, is putting into the world a new set of resources: the intangible goods. Applying the logics of industrial society, the emergence of new goods in itself, already triggers a struggle for its control and its exploitation, as if a new oil well is found or a new virus is discovered. [...] The struggle for the benefit of a new abundance (economy) and the fight against censorship (politics) go hand in hand. Just as Anonymous well points out, copyright and censorship are the same. The changes in the architecture of reality are coming together again what the old world wanted to separate: the economy (copyright and shortages) and politics (opacity and censorship)" (Padilla, 2012: 57 and 60-61). All the translations to English from texts or websites originally in Spanish or Catalan - quoted in this paper- are mine.

${ }^{16}$ Suffice it to mention the situation of Chelsea Manning, the US soldier who confessed to having revealed military secrets to WikiLeaks, after being months in a military prison and having undergone a treatment that has been described as demeaning or quasi torture by the Special Rapporteur on torture and other cruel, inhuman or degrading treatment or punishment of the United Nations (Méndez, 2012). 
consider it legitimate to develop disobedient political actions that do not meet the same normative requirements that offline political and democracy theories have demanded so far - the publicity among them-, giving rise to a totally acceptable and even necessary anonymous cyberactivism.

In light of this general approach, I bring back the original aporia: does WikiLeaks meet the criteria to qualify its action as civil disobedience $?^{17}$

First, disclosing secret documents is an inherently symbolic action. The main objective pursued by Chelsea Manning (2013) was literally to denounce the atrocities that her country was committing in Iraq and Afghanistan, in order to sway public awareness of her fellow citizens, promote a profound social and political change and avoid any more innocent victim. WikiLeaks $(1.1 ; 1.2 ; 3.2 \& 3.3)$ proclaims exactly the same, vindicating precisely the revelation of secrets as a "principled" or morally motivated action with political purposes. Assange (2006; 2010a \& 2010b) takes a similar stance on it.

Regarding the criterion of the peaceful or nonviolent character, although it is obvious that our conclusions would depend largely on the definition of violence we use, I consider it met. Moreover, it is really important to reject the US intention, among other states and multinational companies, to identify the e-leaking as cyberterrorism (Manion \& Goodrum, 2000), by means of an unacceptable analogy between the attack on The World Trade Center in New York and a violation of national cybersecurity, which would constitute a digital 9/11 (Comas, 2014).

What about the criteria of publicity, responsibility and constitutional loyalty? Well, as I have already formulated my argument to demand the relativization or abandonment of these three criteria is the absence of genuine fundamental rights in cyberspace, in addition to all the democratic deficits of the world order. Because of this double defencelessness, the risk of disproportionate penalties, abuse and arbitrariness on the Net is exponentially increased. At least, this global injustice

${ }^{17}$ Nevertheless, before answering this question, we should be sure that WikiLeaks has actually committed an illegality, as a preliminary step to consider whether, in that case, it is possible to apply the concept of civil disobedience. Concerning this aspect, at least two ideas must be taken into account. First, that the applicable legislation to a web service is the one in force in the territory in which the page server is physically located. Therefore, to the extent that it is possible to spread infinitely WikiLeaks servers in multiple mirrors around the world, there is a real option to develop any virtual action in a territory in which this very activity is completely legal. Second, perhaps WikiLeaks is not the subject who starred in the criminal action typified as revealing secrets. In fact, WikiLeaks $(1.2 ; 1.3 \& 3.2)$ and Julian Assange frequently argue that their work is eminently journalistic, acting rather as a means of communication or editing news, rather than as a whistle-blower. If so, its activity could remain completely covered by the constitutional rights of freedom of information and press. In that case, who would be the telltale and, therefore, the suspect or guilty of any crime? Well, it would be the vast majority of anonymous informants who managed to transmit classified data to WikiLeaks, violating data protection laws, state secrets, etc. Thus, WikiLeaks appears under a new light, as a paradoxically opaque society that depends on the absolute ignorance of the identity of their sources, technologically guaranteed. But, despite all this, let's suppose that WikiLeaks itself is the actor who commits the illegal act of e-leaking. 
exempts from the responsibility and the loyalty requirements, making e-leaking legit and even very necessary as a compensatory device. Besides, I can more reasonably justify the breach of the first two conditions: responsibility and publicity.

For Arendt (1972a), it is utterly absurd to demand from a disobedient person the same absolute sanctions' compliance imposed to a delinquent, precisely because disobedience should not be treated as any ordinary crime. Arendt already distinguishes disobeyers from offenders because the former act publicly and without profit. Based on her ideas, ${ }^{18}$ I think it is possible to maintain that same distinction without having the obligation or the responsibility to accept any punishment. It is so because, in reality, this observance is only one of the several ways to practically meet a wider normative criterion, already suggested: to be an altruistic action, not selfish or strategic. ${ }^{19}$ Obviously, voluntarily accepting a sanction is a specific and intuitive case of a non-selfish action, since the subject obeys something that supposedly is against his interest but in favour of the common good. On the contrary, the offender violates the law exclusively to benefit from this individual breach. However, it is a mistake to reduce all forms of altruistic action to those that necessarily undergo punishment or sanction. ${ }^{20}$

Analogously, the knowledge of the people identity is not, indeed, one of the normative criterion that allows to judge the actions as correct. This quotidian example proves it: if an individual subject steals a car for his personal enjoyment, this behaviour will still be a crime despite of making public his name or having previously announced it. So fortunately, publicity is not a sufficient condition. But if an unknown subject makes a peaceful sit-in in the middle of a public square to protest against something considered unjust by public opinion, that is the normative key, this action will remain as valid civil disobedience. And it will be like this both whether the subject has informed in advance of his identity as in the case in which the rest of society and the competent institutions ignore their names - which is the most frequent situation, by the way. Thus, publicity does not seem a necessary condition either.

Nevertheless, the possible confusion between these two different conditions, publicity and identity, must be more clarified. The historical example of the Italian group Tute Bianche is helpful in that regard. ${ }^{21}$ This anti-globalization movement fought in the streets wearing white overalls and hiding their faces. Therefore, they made their identification almost impossible, in order to legally protect themselves. Their invisibility was the only way to denounce the multiple situations of injustice that are systematically concealed from the public scrutiny under global and neoliberal

\footnotetext{
${ }^{18}$ See also Scheuerman (2014).

${ }^{19}$ A concerted, non-violent action (Arendt, 1972b). Or a communicative, non-finalistic or instrumental action (Habermas, 1985b).

${ }^{20}$ Obviously, my argument leads us to another problem: the one of the correct evaluation of the alleged altruism of actions, which exceeds this paper. In any case, responsibility could also be accepted in cyberspace, provided that no sanction would endanger the personal integrity of the disobedient or there is a due legal process.
}

${ }^{21}$ Cf. Iglesias (2002 \& 2003) and Comas (2016). 
capitalism (Associazione Ya Basta!, 1999). In my opinion, their offline practice represented already, in the late nineties, a good example of anonymous civil disobedience. And they teach us that the indispensable requirement of publicity is totally compatible and consistent with anonymity, because it does not demand the identity of the actors. But, at least, it does entail the public character of the action itself, its reasonable justifications or its political effects. Consequently, I absolve any action from the identity requirement to be qualified as civil disobedience, because this is a non-essential condition -although it certainly increases social sympathy, just like the acceptance of the sanction.

To sum up, the underlying grounds that legitimate the e-leaking are the altruistic nature of the method chosen in action, in addition to the majority consideration of the unjust character of the violated law. But in deliberative terms, i.e. the intersubjective recognition by all those affected, achieved through a struggle for hegemonic public opinion, in the context of an inclusive democracy and a discursive and dynamic rule of law.

\section{CONCLUSION}

My final claim is that we could only apply the concept of civil disobedience to the eleaking of secrets if these new four conditions are accepted: a) It is allowed to carry out this practice anonymously; b) It is exempted from the unavoidable obligation to assume any punishment for it; c) It is not necessarily required the acceptance of the entire legal system that frames the e-leaking; d) The area of performance of civil disobedience is refocused, to adapt it both to transnational power relationships as to the Internet.

In truth, there is a gradation in these exceptions, as the last two requirements do not seem as indispensable as the first two. Specifically, I argue that it is practically feasible to reconfigure the notion of civil disobedience for its digital practice, provided that its agents are allowed at least to remain anonymous and unpunished. ${ }^{22}$ And that, regardless of whether they accept or not the legal and political frame of their

${ }^{22}$ Obviously, my proposal exclusively demands not to censure or penalize the specific action of leaking confidential information - which must also have social, ethical, political or economic relevance. Any other criminal action associated with e-leaking, but independent of it, must be sanctioned indeed. And severely, to protect the valuable legal certainty and integrity that we want both for the democratic political community as the disobedient practice itself. For example, if you have committed a murder or assault to obtain the information, such conducts must be punishable. But the whistle-blower who already has (access to) the secret information should not be punished for revealing it. Therefore, WikiLeaks primarily appeals to the ethical conscience of all those who, for professional or other reasons, are everyday or casually in contact with that kind of information without breaking any law to get it -in this subjective appeal, WikiLeaks reminds of Thoreau (1849). Obviously, accepting also the action itself of illegally accessing that information, actively and not merely passive - what makes WikiLeaks, simply receives the data-, would lead to new theoretical and normative disquisitions. 
communicative praxis, and regardless of the institutional level involved -local, national, international or transnational.

Obviously, the leaking of secrets could also be conceived as civil disobedience without being virtually developed through the ICT - protecting in that way the actions of informers and confidants lifelong, so to speak. What happens is that, precisely, cyberspace seems nowadays the only sphere that can meet the first two conditions: anonymity and impunity. ${ }^{23}$ Therefore, I am afraid that any disclosure of confidential information that wants to meet the new requirements of civil disobedience must be an e-leaking.

\section{REFERENCES}

ARENDT, Hannah (1972a [1971]). "Civil Disobedience", in Crises of the Republic. New York: Harvest Book, 49-102.

- (1972b [1970]). "On violence", in Crises of the Republic. New York: Harvest Book, 103-198.

ASSANGE, Julian (2006). "State and Terrorist Conspiracies", visited on 10-11-2006, https://cryptome.org/0002/ja-conspiracies.pdf

- (2010a). "The Whistleblower", Oslo Freedom Forum, April 27, visited on 15-102012, https://www.youtube.com/watch?v=4S6002S8PTU

- (2010b). "Julian Assange, el incordio del Pentágono", El País, visited on 22-082011, http://sociedad.elpais.com/sociedad/2010/10/22/videos/1287698401_870215.ht $\mathrm{ml}$

ASSOCIAZIONE YA BASTA! (1999). "The Age of Clandestinity", visited on 20-062015, http://nycyabasta.mayfirst.org/documents/aoc.html

CASTELLS, Manuel (2000-2001). "Internet y la Sociedad Red", Lliçó inaugural del programa de doctorat sobre la societat de la informació $i$ el coneixement, Barcelona, Universitat Oberta de Catalunya (UOC), visited on 14-03-2012, http://www.uoc.edu/web/cat/articles/castells/print.html

${ }^{23}$ I repeat: this impunity would always be limited. It would not be a "license to kill" and it would clearly differ from the "irresponsibility and inviolability" that the Spanish Head of State enjoys under our Constitution - which is particularly embodied in the King, but it could be another personality-, to the extent that they only cover the actions and behaviours of him as such. It would not be an absolute immunity of the person because of his position, but a rigorous and relative decriminalization of the action. Perhaps, through a new kind of justification for the wrongful act that would validate its undeniable wrongfulness, in analogy with self-defense, extreme necessity, etc. Hence my extravagance of proposing the "legalization of civil disobedience", which might seem an oxymoron but I think doctrinally coherent. In any case, there is a crucial technical issue: if cryptography makes identities of informants untraceable and unknowable, the impunity of the e-leakers would be virtually absolute, since by definition, with no person to whom attribute the crime, this does not exist. 
COMAS, Miquel (2011a). “Cómo interpretar que EEUU suplique a "WikiLeaks" que no publique más información secreta?". Astrolabio, Revista Internacional de Filosofía, 11, 116-127.

- (2011b). "Límites y contradicciones en la crítica de WikiLeaks a las "tiranías empresariales"", in BARRIENTOS, José \& MÉNDEZ, Joan (eds.) (2011). Filosofía y espacios sociales. Madrid: Visión Libros, 43-56.

- (2012a). "El caso WikiLeaks como piedra de toque de la democracia deliberativa de Jürgen Habermas". Dilemata, Revista Internacional de Éticas Aplicadas, 8, 123151.

- (2012b). "El meu nom és Assange, Julian Assange (i vull Ilicència per informar)". Astrolabio: revista internacional de filosofía, 13, 129-139.

- (2014). "WikiLeaks com a autor d'un 11-S digital: terrorisme electrònic o ciberconspiració governamental?", in COMAS, Miquel \& MATAS, Arnau (eds.) (2014). Tecnocrítica: la cruïlla entre tecnologia i moviments socials. Palma: Edicions UIB, 103-135.

- (2016). "Lecciones del grupo antiglobalización Tute Bianche sobre la desobediencia civil digital y el sujeto "revolucionario"". Paper held in the 13th Political Philosophy Conference - Displacements of Power and Criticism (University of Barcelona, 2016). Forthcoming in Astrolabio: Revista Internacional de Filosofía.

DE UGARTE, David (2004). Breve historia del análisis de redes sociales. Origen y fundamentación de la metodología del análisis de redes sociales. El Correo de las Indias, http://lasindias.com/gomi/historia_del_analisis_de_redes_sociales.pdf

- (2011 [2007]). El poder de las redes: manual ilustrado para personas, colectivos y empresas abocados al ciberactivismo. Barcelona: Ediciones El Cobre.

DWORKIN, Ronald (1978 [1977]). "Civil Disobedience", in Taking Rights Seriously. Cambridge: Harvard University Press, 206-222.

FRASER, Nancy \& HONNETH, Axel (2003). Redistribution Or Recognition?: A Political-philosophical Exchange. London \& New York: Verso.

IGLESIAS, Pablo (2002). "Desobediencia civil y movimiento antiglobalización. Una herramienta de intervención política". Revista Telemática de Filosofía del Derecho, $n^{\circ} 5,2001 / 2002,213-251$.

- (2003). "El movimiento de los tute bianche. Experiencias y estrategias". Paper held in the summer workshop Derechos Humanos, globalización y educación para la paz (University of León). Visited on 28-3-2016, http://www.sindominio.net/ pablo/papers_propios/El_movimiento_de_los_tute_bianche.pdf

HABERMAS, Jürgen (1985a [1983]). "Civil Disobedience: Litmus Test for the Democratic Constitutional State". Berkeley Journal of Sociology, vol. 30, 95-116.

- (1985b [1981]). The Theory of Communicative Action, vol. 1. Boston: Beacon Press.

- (1988 [1963]). Theory and Practice. Boston: Beacon Press.

HOBBES, Thomas (2012 [1651]). Leviathan. Oxford University Press. 
MANION, Mark \& GOODRUM, Abby (2000). "Terrorism or Civil Disobedience: Toward a Hacktivist Ethic". Computers and Society, vol. 30, issue 2, 14-19.

MANNING, Chelsea (2013). "In Her Own Words", Free Chelsea Manning, visited on 13-06-2015, https://www.chelseamanning.org/learn-more/in-his-own-words

MÉNDEZ, Juan (2012). "Bradley Manning's treatment was cruel and inhuman, UN torture chief rules". The Guardian, visited on 15-06-2015, http://www.theguardian.com/world/2012/mar/12/bradley-manning-cruel-inhuman-treatment-un

PADILLA, Margarita (2012). El kit de la lucha en Internet. Para viejos militantes y nuevas activistas. Madrid: Traficantes de Sueños.

RAWLS, John (1999 [1971]). A Theory of Justice (revised edition). Cambridge: The Belknap Press of Harvard University Press.

SCHEUERMAN, William E. (2014). "Whistleblowing as civil disobedience: The case of Edward Snowden". Philosophy and Social Criticism, vol. 40 (7), 609-628.

STALLMAN, Richard (2010). "The Anonymous WikiLeaks protests are a mass demo against control". The Guardian, visited on 17-12-2010, https://www.theguardian.com/commentisfree/2010/dec/17/anonymous-wikileaks-protest-amazon-mastercard

THOREAU, Henri David (1849). On the Duty of Civil Disobedience.

WIKILEAKS (1.1). ${ }^{24}$ "What is WikiLeaks?".

- (1.2). "How WikiLeaks works".

- (1.3). "Why the media (and particularly WikiLeaks) is important".

- (3.2). "The importance of principled leaking to journalism, good government and a healthy society".

- (3.3). "Should the press really be free?".

WRAY, Stefan (1998). "Electronic Civil Disobedience and the World Wide Web of Hacktivism: A Mapping of Extraparliamentarian Direct Action Net Politics". Switch, vol. 4, num. 2.

ZAFRA, Remedios (2010). Un cuarto propio conectado. Madrid: Fórcola Ediciones.

${ }^{24}$ In brackets, it is indicated the point or section where the reference appears, following the very specifications of the website itself under this $h t m /$ link: https://wikileaks.org/About.html. Everything visited on 01-11-2014. 